REFLEKSI HUKUM

Jurnal Ilmu Hukum
p-ISSN 2541-4984 | e-ISSN 2541-5417

Volume 5 Nomor 1, Oktober 2020, Halaman 1-20

DOI: https://doi.org/10.24246/jrh.2020.v5.i1.p1-20

Open access at: http://ejournal.uksw.edu/refleksihukum

Penerbit: Fakultas Hukum Universitas Kristen Satya Wacana

\title{
MAHKAMAH KONSTITUSI DAN UPAYA MENEGAKKAN ASAS PRESIDENSIALISME DI INDONESIA
}

\author{
Kuswanto Kusnadi \\ Fakultas Hukum Universitas Darul Ulum \\ Korespondensi: kuswanto.undar@gmail.com
}

Naskah diterima: 16 Januari 2020|Direvisi: 28 Januari 2020|Disetujui: 23 September 2020

\begin{abstract}
Abstrak
Artikel ini membahas tentang peranan Mahkamah Konstitusi dalam menegakkan asas presidensialisme di Indonesia. Artikel ini berargumen bahwa meskipun Mahkamah Konstitusi tidak secara jelas mendukung kebijakan legislatif dalam rangka penyederhanaan partai politik, namun Mahkamah Konstitusi secara kuat mendukung asas bahwa sistem presidensial harus mengatasi kontestasi politik. Argumen tersebut dihasilkan dari analisis putusan-putusan Mahkamah Konstitusi dalam menguji konstitusionalitas undang-undang. Upaya Mahkamah Konstitusi dalam mempertahankan asas presidensialisme nampak dalam kasus ambang batas elektoral, ambang batas parlemen, pemilu presiden dan ambang batas pencalonan presiden. Isu utama dari kasus-kasus tersebut memunculkan kebutuhan untuk melakukan reformasi terhadap sistem kepartaian yang sesuai dengan sistem presidensial sebagai asas konstitusi di Indonesia.
\end{abstract}

Kata Kunci: Mahkamah Konstitusi; Presidensialisme; Penegakan.

\begin{abstract}
This article examines the role of the Constitutional Court in enforcing presidentialism principle in Indonesia. This article argues that while the Constitutional Court does not clearly agree with the legislative policy to decrease the number of political parties, it strongly supports the principle that presidentialism should prevail over political contestation. This argument resulted from the analysis of the the Constitutional Court's case law in reviewing the constitutionality of legislation. The Constitutional Court's effort to upheld presidentialism principle can be seen from electoral threshold case, parliamentary threshold cases, presidential election case and presidential threshold case. The main issue of the cases raises the need for political party system reform compatible with the presidential system as constitutional principle in Indonesia.
\end{abstract}

Keywords: Constitutional Court; Presidentialism; Enforcement. 


\section{PENDAHULUAN}

Dalam penyelenggaraan ketatanegaraan di Indonesia pascaReformasi 1998, kehadiran Mahkamah Konstitusi Republik Indonesia (MK) sangat penting maknanya guna menjamin pemerintahan berdasarkan pada konstitusi secara konsisten. MK memiliki fungsi yang unik terkait dengan kewenangan-kewenangan konstitusionalnya yang salah satunya adalah untuk melakukan pengujian yudisial konstitusionalitas undangundang. ${ }^{1}$ Terkait dengan itu, salah satu peranan penting yang dijalankan oleh MK tetapi tidak banyak disinggung secara spesifik adalah partisipasinya dalam upaya menegakkan asas presidensialisme di Indonesia. Untuk itu, artikel ini hendak mendiskusikan keterlibatan MK dalam melakukan pengujian konstitusionalitas undang-undang di mana yang menjadi isu substantifnya adalah penerapan asas presidensialisme sebagai asas dari Undang-Undang Dasar Negara Republik Indonesia Tahun 1945 (UUD NRI 1945).

Terhadap isu tersebut penulis berargumen bahwa kontribusi MK cukup aktif dalam mendukung penguatan sistem pemerintahan Indonesia menurut UUD NRI 1945 yang didasarkan pada asas presidensialisme, walaupun tidak sepenuhnya dilakukan secara taat asas. Untuk sampai pada pendapat tersebut maka artikel ini akan mendiskusikan beberapa hal sebagai berikut. Pertama, menjelaskan asas presidensialisme sebagai asas UUD
NRI 1945 beserta realitas politik sebagai media operasionalnya yang cenderung bersifat sebagai hambatan institusional. Kedua, memaparkan praktik-praktik pengujian konstitusionalitas undang-undang yang secara ratione materiae relevan dengan keberlakuan asas presidensialisme. Ketiga, memberikan penilaian atas praktik MK tersebut sebagai upaya dalam rangka menegakkan asas presidensialisme di Indonesia.

\section{PEMBAHASAN}

\section{Presidensialisme sebagai Asas UUD NRI 1945 dan Hambatan Institusional Sistem Multi Partai}

Diskusi tentang presidensialisme pada hakikatnya adalah diskusi tentang sistem pemerintahan, yang dalam hal ini berkaitan dengan: "constitutional models set out rules for the formation and termination of governments." 2 Secara substantif, meskipun tidak dinyatakan secara formal, UUD NRI 1945 menganut asas presidensialisme sebagai sistem pemerintahan yang hendak dijalankan konstitusi. Kesimpulan tersebut dapat dihasilkan melalui penyelidikan secara cermat terhadap ketentuanketentuan UUD NRI 1945 dengan menggunakan pendekatan konseptual, dalam hal ini Teori Konstitusi.

C.F. Strong menjelaskan pengertian inti sistem presidensial sebagai "the conception of independence of the executive from the

Pasal 24C ayat (1) UUD 1945.

Cindy Skach, 'The 'Newest' of Separation of Powers: Semipresidentialism' (2007) 5(1) International Journal of Constitutional Law 93, 95. 
legislative."3 Juan J. Linz menambahkan untuk konsepsi sistem presidensial sebagai berikut:

In presidential systems an executive
with considerable constitutional
powers-generally including full
control of the composition of the
cabinet and administration-is directly
elected by the people for a fixed term
and is independent of parliamentary
votes of confidence. He is not only the
holder of executive power but also the
symbolic head of State and can be
removed between elections only by
the drastic step of impeachment.

Pendapat demikian dikukuhkan oleh Denny Indrayana yang menjelaskan bahwa sistem presidensial tidak hanya meletakkan presiden sebagai pusat kekuasaan eksekutif, tetapi juga pusat kekuasaan negara di mana presiden tidak hanya sebagai kepala pemerintahan (Chief of Executive), tetapi juga sebagai kepala negara (Chief of State). Sebagai implikasinya, rentang kekuasaan presiden tidak hanya menyentuh wilayah kekuasaan eksekutif, tetapi juga fungsi legislasi dan yudisial. ${ }^{5}$

Sesuai penjelasan di atas, UUD NRI 1945 memiliki kecenderungan lebih kuat untuk dikualifikasi sebagai konstitusi presidensial ketimbang konstitusi parlementarian. Kesimpulan ini dapat dijustifikasi dengan mempertanyakan apakah ketentuan-ketentuan dalam UUD NRI 1945 mampu memenuhi tuntutantuntutan dari pengertian teoretiskonseptual mengenai konstitusi presidensial sebagaimana dipaparkan di atas. Untuk itu, yang pertama-tama harus dijadikan sebagai unit analisis adalah prosedur pengisian jabatan presiden. Pasal 6A ayat (1) UUD NRI 1945 menentukan: "Presiden dan Wakil Presiden dipilih dalam satu pasangan secara langsung oleh rakyat." Pemilihan presiden dan wakil presiden secara langsung pada hakikatnya adalah bentuk komitmen atas independensi presiden dari badan legislatif. Jelas bahwa jika kriteria pertama ini yang dijadikan sebagai indikator untuk sistem presidensial maka UUD NRI 1945 sudah memenuhinya.

Kedua, masa jabatan presiden yang bersifat tetap (fix term). Pasal 7 UUD NRI 1945 menentukan: "Presiden dan Wakil Presiden memegang jabatan selama lima tahun, dan sesudahnya dapat dipilih kembali dalam jabatan yang sama, hanya untuk satu kali masa jabatan." Ketentuan ini harus dikaitkan dengan Pasal 7A UUD NRI 1945 yang memuat ketentuan tentang alasan pemberhentian presiden dan/atau wakil presiden dalam masa jabatannya, yaitu: “... apabila terbukti telah melakukan pelanggaran hukum berupa pengkhianatan terhadap negara, korupsi, penyuapan, tindak pidana berat lainnya, atau perbuatan tercela maupun apabila terbukti tidak lagi memenuhi syarat sebagai Presiden dan/atau Wakil Presiden." Sesuai dengan semangat asas presidensialisme maka perihal pemberhentian presiden dalam masa jabatannya diatur mekanisme khusus untuk memperkuat posisi presiden, yang merupakan antitesis dari sistem parlementer, yaitu adanya putusan

C.F. Strong, Modern Political Constitution (5th edn, Sidwick dan Jackson Ltd. 1975) 233.

Juan J. Linz, 'The Perils of Presidentialism' (1990) 1 (1) Journal of Democracy 51, 52. Lihat juga Scott Mainwaring dan Matthew S. Shugart, 'Juan J. Linz, Presidentialism and Democracy' (1997) 29 (4) Comparative Politics 449, 449.

$5 \quad$ Saldi Isra, Pergeseran Fungsi Legislasi: Menguatnya Model Legislasi Parlementer dalam Sistem Presidensial Indonesia (1st edn, PT RajaGrafindo Persada 2010) 38. 
yudisial untuk menentukan apakah presiden dan/atau wakil presiden bersalah atas pelanggaran hukum yang disangkakan (Pasal 7B UUD NRI 1945). Hal ini semakin menegaskan adanya independensi eksekutif dari legislatif di mana alasan untuk pemberhentian presiden adalah alasan hukum, bukan alasan politik.

Secara filosofis, sistem presidensial memiliki hakikat memperkuat posisi presiden dalam pemerintahan karena karakternya sebagai pemegang kekuasaan eksekutif, dan sekaligus kepalanya, menghendaki itu. ${ }^{6}$ Konsepsi demikian dikemukakan oleh Thomas Jefferson, Presiden Amerika Serikat. Konsepsi Jefferson tentang kekuasaan kepresidenan adalah:

The president unifies the will of the nation and thereby embodies it. The source of the president's claim to embody the will of the nation is his mode of election; because the president is the single nationally elected officer, the president can claim, more than members of Congress, to represent the national will. Because the president must be able to execute that will, it must be surprisingly strong, or energetic. ${ }^{7}$

Berbeda dengan badan pemerintahan yang lain, yaitu legislatif, presiden merupakan pemersatu kehendak bangsa, dan menyatu dengannya. Kedudukan ini terbangun melalui sistem pemilihannya di mana presiden adalah satu-satunya pejabat yang dipilih secara nasional. Dalam kaitan dengan fungsi perwakilan terhadap kehendak bangsa, maka presiden lebih kuat statusnya ketimbang badan legislatif. Oleh karena itu, karakter dari kekuasaan kepresidenan seharusnya adalah "strong and energetic". Karakter demikian hanya inheren dalam sistem presidensial yang menganut sistem pemisahan kekuasaan. ${ }^{8}$

Untuk

keberhasilan pemerintahan berdasarkan sistem presidensial maka dibutuhkan dukungan institusional berupa sistem kepartaian yang tepat. Sesuai dengan praktik politik yang berlangsung di Indonesia, sistem kepartaian yang berlaku adalah sistem multi partai. Terhadap permasalahan dalam hubungan antara sistem presidensial dengan sistem multi partai, para ilmuwan politik telah berhasil mencapai konsensus bahwa kedua konsep tidak kompatibel karena kodratnya yang saling bertolak belakang. Linz dengan gamblang mengajukan tesis bahwa sistem parlementer lebih stabil ketimbang sistem presidensial dalam hal dukungan parlemen terhadap eksekutif. 9

Secara internal, konsep sistem presidensial sendiri mengandung paradoks jika hendak disejajarkan dengan demokrasi, khususnya menyangkut posisi saling berhadapan antara presiden/eksekutif dengan parlemen/legislatif. Paradoks ini menyulitkan dalam membangun sistem hubungan keduanya secara

6 Steven G. Calabresi, "The Virtues of Presidential Government: Why Professor Ackerman is Wrong to Prefer the German to the U.S. Constitution' (2001) 18 (1) Constitutional Commentary 51, 61. Jeremy D. Bailey, Thomas Jefferson and Executive Power (1st edn, Cambridge University Press 2009) 9-10.

8 Susan Rose-Ackerman, Diane A. Desierto dan Natalia Volosin, 'Hyper-Presidentialism: Separation of Powers without Checks and Balances in Argentina and the Philippines' (2011) 29 (1) Berkeley Journal of International Law 246, 247-248.

$9 \quad \operatorname{Linz}(\mathrm{n} 3)$ 51. Lihat juga Bruce Ackerman, 'The New Separation of Powers' (2000) 113 (3) Harvard Law Review 633, 643-652. 
demokratis. Linz berpendapat tentang hal ini sebagai berikut:

On the one hand, such systems set out to create a strong, stable executive with enough plebiscitarian legitimation to stand fast against the array of particular interests represented in the legislature ... On the other hand, presidential constitutions also reflect profound suspicion of the personalization of power: memories and fears of kings and caudillos do not dissipate easily $\ldots 10$

Scott Mainwaring dan Matthew Shugart menjelaskan potensi rivalitas eksekutif dengan legislatif karena masing-masing memiliki klaim atas legitimasi yang bersaing. Permasalahan serius akan terjadi manakala keduanya yang sama-sama legitimate sebagai lembaga perwakilan rakyat memiliki kebijakan berbeda. ${ }^{11}$ Dalam kaitan dengan sistem multi partai, kelemahan sistem presidensial adalah kemungkinan hadirnya presiden minoritas (minority president) dan pemerintahan terbelah (divided government). Meskipun memperoleh mandat kuat dari rakyat, akan tetapi dengan posisi minoritas, agenda pemerintahan yang dijalankan presiden dapat terhambat oleh parlemen.

Pada kesempatan lain Mainwaring mengemukakan pendapatnya yang menjelaskan tiga faktor mengapa terjadi kesulitan dalam kombinasi sistem presidensial dengan sistem multi partai dikaitkan dengan pembentukan koalisi parlemen oleh presiden sebagai berikut:
In presidential systems the president (not the parties) has the responsibility of putting together a cabinet. The president may make prior deals with the parties that support him or her, but these deals are not as binding as they are in a parliamentary system. Presidents are freer to dismiss ministers and to rearrange the cabinet than prime ministers in a coalition government are ...

... in presidential systems, the commitment of individual legislators to support an agreement negotiated by the party leadership is often less secure. The extension of a cabinet portfolio does not necessarily imply party support for the president, as it does in a parliamentary system ...

... incentives for parties to break coalitions are stronger in presidential systems than in many parliamentary systems. In multiparty presidential systems, as new presidential elections appear on the horizon, party leaders generally feel a need to distance themselves from the president in office. By remaining a silent partner in a governing coalition, party leaders fear they will lose their own identity, share the blame for government mistakes, and not reap the benefits of its accomplishments. ${ }^{12}$

Untuk pembentukan koalisi Mainwaring berpendapat bahwa pada sistem multi partai, kombinasi paling tepat adalah dengan sistem parlementer karena kuatnya faktor solidaritas dan soliditas dikaitkan dengan kepentingan antara eksekutif dan legislatif yang lebih saling bergantung dan saling menguntungkan. Dorongan berkoalisi sangat kuat dibandingkan pada sistem presidensial. 13

\footnotetext{
$10 \quad \operatorname{Linz}(\mathrm{n} 4) 54$.

11 Scott Mainwaring dan Matthew Shugart, 'Juan Linz, Presidentialism and Democracy: A Critical Appraisal' (1993) Kellog Institute for International Studies, Working Paper No. 200, 2.

12 Scott Mainwaring, 'Presidentialism, Multipartism and Democracy: The Difficult Combination' dalam Robert A. Dahl, et.al., eds., The Democracy Sourcebook (1st edn, The MIT Press 2003) 270271.

13 Ibid.
} 
Pendapat Mainwaring didukung oleh Jose Antonio Cheibub yang melihat masalah ini juga dari aspek hambatan untuk membangun koalisi. Untuk stabilitas sistem presidensial, dibutuhkan perolehan suara mayoritas di parlemen pada partai politik pendukung presiden. Dalam kompetisi politik di bawah sistem multi partai hal itu terbukti tidak mungkin sehingga presiden terpilih dipaksa untuk melakukan koalisi. Dalam konteks itu ada tiga faktor penghalang bagi terbangunnya koalisi yang bersifat institusional yaitu kecenderungan presiden tidak ingin bekerja sama karena mekanisme kerjanya berdasarkan pemisahan kekuasaan, sikap non-kompromis karena mendapat mandat sangat kuat dari rakyat melalui pemilihan langsung dan posisi presiden yang sangat menentukan dalam sistem presidensial mendorong kecenderungan politik zero-sum. ${ }^{14}$ Oleh karena itu, jika sistem presidensial dipandang sebagai asas yang tepat maka isu yang perlu diberikan solusi adalah sistem kepartaian yang tepat. Dengan demikian, karena sistem multi partai tidak tepat jika disandingkan dengan sistem presidensial maka penyederhanaan partai politik menjadi niscaya dalam rangka penguatan sistem presidensial. ${ }^{15}$

\section{Pengujian Konstitusionalitas \\ Undang-Undang Berbasis Asas \\ Presidensialisme}

$\begin{array}{cr}\text { Secara } & \text { garis besar, upaya MK } \\ \text { dalam } & \text { menegakkan }\end{array}$ presidensialisme dapat dilihat dari pendapat-pendapat yudisialnya atas isu penyederhanaan partai politik dan isu periode penyelenggaraan pemilu legislatif - pemilu presiden. Pendapat yudisial terhadap isu penyederhanaan partai politik merupakan indikator untuk memahami peran MK dalam menegakkan asas presidensialisme karena penyederhanaan partai politik adalah pra-kondisi untuk penguatan sistem presidensial. Begitu pula halnya dengan isu periode penyelenggaraan pemilu legislatif pemilu presiden juga sangat terkait dengan penguatan sistem presidensial karena diyakini mampu menimbulkan efek penyederhanaan partai politik (coattail effect).

\section{Electoral Threshold (ET)}

Menjelang pemilu demokratis pertama era reformasi tahun 1999, lahir banyak partai politik yang hendak berkompetisi dalam pemilu legislatif. Untuk menunjang pelaksanaan pemilu 1999 dihasilkan perangkat hukum berupa: (1) UU No. 2 Tahun 1999 tentang Partai Politik, (2) UU No. 3 Tahun 1999 tentang Pemilihan Umum, serta (3) UU No. 4 Tahun 1999 tentang Susunan dan Kedudukan MPR, DPR, dan DPRD. Konsekuensi dari UU No. 2 Tahun 1999 yang memperlakukan semua partai politik secara sama melahirkan sistem multipartai di Indonesia. 141 partai politik memperoleh pengesahan status badan hukum dari Departemen Hukum dan HAM. Berdasarkan verifikasi administratif dan faktual

\footnotetext{
14 Jose Antonio Cheibub, Presidentialism, Parliamentarism and Democracy (1st edn, Cambridge University Press 2007) 8-9.

15 Kuswanto, Penyederhanaan Partai Politik: Penguatan Sistem Presidensial dalam Perspektif Pancasila dan Konstitusi (1st edn, Intelegensia Media 2016) 132-137.
} 
yang dilakukan oleh Komisi Pemilihan Umum ada 48 partai politik yang eligible untuk mengikuti pemilu 1999. Pada pemilu yang dilaksanakan tanggal 7 Juni 1999, ada 21 partai politik yang berhak mendapatkan kursi DPR. Namun hanya 6 partai politik yang perolehan kursinya di atas 10 kursi, yaitu: PDIP; Partai Golkar; PPP; PKB; PAN dan PBB. ${ }^{16}$

Mengantisipasi dampak negatif dari sistem multi partai, Pasal 39 ayat (3) UU No. 3 Tahun 1999 memberlakukan ketentuan electoral threshold (ET) yang menentukan bahwa untuk dapat mengikuti pemilu selanjutnya, partai politik harus memiliki sekurang-kurangnya $2 \%$ dari jumlah kursi DPR, atau sekurangkurangnya 3\% kursi dari jumlah kursi DPRD I atau DPRD II yang tersebar sekurang-kurangnya di $1 / 2$ jumlah provinsi dan di $1 / 2$ jumlah kabupaten/kota di seluruh Indonesia. Berdasarkan hasil perolehan kursi di DPR pada pemilu 1999, hanya ada 6 partai politik yang secara otomatis eligible untuk mengikuti pemilu 2004, yaitu: PDIP, Partai Golkar, PPP, PKB, PAN dan PBB.

Ketentuan ET sebagai bentuk pembatasan terhadap partisipasi partai politik dalam pemerintahan kemudian diuji secara tidak langsung oleh MK pada tahun 2003. Dalam kasus ini MK memberikan obiter dictum $^{17}$ yang sependapat dengan pembentuk undang-undang bahwa ET konstitusional karena merupakan ranah kebijakan dari pembentuk undang-undang dalam menjalankan Pasal 22E ayat (6) UUD NRI 1945.18 Dalam pengujian secara khusus terhadap Pasal 9 ayat (1) dan (2) UU No. 12 Tahun 2003 tentang Pemilihan Umum Anggota Dewan Perwakilan Rakyat, Dewan Perwakilan Daerah dan Dewan Perwakilan Rakyat Daerah atas permohonan partai-partai politik yang tidak memenuhi ketentuan ET untuk mengikuti pemilu tahun 2009, MK berpendapat:

Pasal 9 ayat (1) dan ayat (2) UU
Pemilu tidak bertentangan dengan
Pasal $28 I$ ayat (2) UUD 1945 tentang
hak untuk bebas dari perlakuan
yang bersifat diskriminatif, karena
persyaratan untuk dapat mengikuti
pemilu berikutnya itu berlaku untuk
semua partai politik setelah
melewati kompetisi secara
demokratis melalui pemilu.
Terpenuhi atau tidak terpenuhinya
ketentuan ET yang menjadi syarat
untuk ikut pemilu berikutnya
tergantung partai politik yang
bersangkutan dan dukungan dari
pemilih, bukan kesalahan undang-
undangnya. 19 Pendapat ini sangat penting karena langsung tertuju pada aspek substantif pemberlakuan ET dari aspek HAM, yaitu apakah kebijakan tersebut melanggar HAM, yaitu diskriminatif seperti didalilkan oleh pemohon. Dengan pendirian MK yang menyatakan kebijakan tersebut tidak diskriminatif maka hal ini merupakan preseden bahwa pemberlakuan threshold (dalam hal ini ET) bukan pelanggaran HAM.

\footnotetext{
16 Muchammad Ali Safa'at, Pembubaran Partai Politik di Indonesia: Analisis Pengaturan Hukum dan Praktik Pembubaran Partai Politik 1959-2004 (Disertasi, Universitas Indonesia 2009) 231.

17 Dalam kasus ini pendapat MK dikualifikasi sebagai obiter dictum, bukan ratio decidendi, karena pendapat tersebut tidak menyangkut isu hukum utama kasus ini, Putusan MK RI No. 002/PUUII/2004. Isu utama kasus a quo adalah penetapan calon anggota DPR/DPRD berdasarkan nomor urut, bukan berdasarkan perolehan suara masing-masing calon (vide Pasal 107 ayat [2] huruf 'b UU No. 13 Tahun 2003).

18 Putusan MK No. 002/PUU-II/2004, Mahkamah Konstitusi, 22 April 2004, 26.

19 Putusan MK No. 16/PUU-V/2007, Mahkamah Konstitusi, 23 Oktober 2007, 82-83.
} 
Selanjutnya MK memberikan pendapat yudisial spesifik terkait dengan konstitusionalitas ET sebagai berikut:

eksistensi partai politik dengan keikutsertaan partai politik dalam pemilu memang merupakan dua hal yang berbeda dan tidak dapat dicampuradukkan ... karena UUD 1945 nyatanya memberikan mandat bebas kepada pembentuk undangundang untuk mengaturnya, termasuk mengenai persyaratan untuk dapat mengikuti pemilu berikutnya dengan ketentuan ET. ${ }^{20}$

MK tidak hanya berpendapat bahwa pembentuk undang-undang bebas dalam merumuskan ketentuan ET, tetapi juga sekaligus menjustifikasi aspek fairness-nya:

... para Pemohon seharusnya sudah sangat memahami sejak dini bahwa ketentuan tentang ET tersebut memang merupakan pilihan kebijakan dari pembentuk undangundang dalam rangka membangun suatu sistem multipartai sederhana di Indonesia. Menurut Mahkamah, kebijakan hukum (legal policy) di bidang kepartaian dan pemilu tersebut bersifat objektif, dalam arti sebagai seleksi alamiah dan demokratis untuk menyederhanakan sistem multipartai yang hidup kembali di Indonesia di era reformasi, setelah dianutnya sistem tiga partai pada era Orde Baru melalui penggabungan partai yang dipaksakan. Dalam hal ini, di antara para Pemohon bahkan ada yang ikut menentukan besaran ET tersebut, dan secara keseluruhan para Pemohon dengan mengikuti Pemilu 2004 berarti secara sadar sudah menerima adanya ketentuan tentang ET dalam UU Pemilu. ${ }^{21}$

Dengan pendapat tersebut dapat disimpulkan sebagai konsekuensinya bahwa kebijakan pemberlakuan ET, berdasarkan UU No. 12 Tahun 2003, adalah kebijakan yang adil karena: ada prior informed consent kepada pemohon sendiri (para pemohon dengan mengikuti pemilu 2004 secara sadar menerima ketentuan ET dalam UU No. 12 Tahun 2003); ET sebagai kebijakan legislasi yang dijalankan oleh pembentuk undang-undang tidak dilakukan secara sewenang-wenang seperti model fusi yang dilakukan oleh rezim Orde Baru.

\section{Parliamentary Threshold (PT)}

Belajar dari pengalaman hasil pemilu 1999, pembentuk undangundang merancang kebijakan baru dalam rangka membatasi partisipasi partai politik di parlemen (DPR). Problematik utama dari sistem multipartai yang hendak diberikan solusi melalui kebijakan ini adalah fragmentasi kekuatan politik di DPR karena tidak ada partai politik yang berhasil meraih suara mayoritas dalam pemilu dan penguasaan kursi di DPR. Hal ini mempersulit proses pengambilan keputusan di DPR sendiri, terutama dalam hubungan dengan Presiden.

Kebijakan baru pembentuk
undang-undang dalam rangka
penyederhanaan partai politik ini
dikenal dengan istilah parliamentary threshold (PT) atau ambang batas parlemen. PT berkenaan dengan persyaratan ambang batas sebagai hak bagi partai politik peraih suara dalam pemilu untuk mendudukkan wakilnya sebagai anggota DPR/DPRD. Kebijakan PT mulai diberlakukan dalam UU No. 10 Tahun 2008 tentang Pemilihan Umum Anggota Dewan Perwakilan Rakyat, Dewan Perwakilan Daerah dan Dewan Perwakilan Rakyat $\begin{array}{ll}20 & \text { Ibid., } 83 . \\ 21 & \text { Ibid. }\end{array}$ 
Daerah menggantikan kebijakan ET UU No. 12 Tahun 2003 yang tidak efektif.

Pasal 202 ayat (1) UU No. 10 Tahun 2008 yang dimaknai sebagai kebijakan pemberlakuan PT menentukan: "Partai Politik Peserta pemilu harus memenuhi ambang batas perolehan suara sekurangkurangnya 2,5\% (dua koma lima perseratus) dari jumlah suara sah secara nasional untuk diikutkan dalam penentuan perolehan kursi DPR." Partai politik yang tidak mampu memperoleh jumlah suara sekurangkurangnya $2,5 \%$ dari suara sah tidak dapat menempatkan wakilnya di DPR, walaupun perolehan suara tersebut mencukupi untuk jumlah kursi tertentu. Dampak yang diharapkan dari kebijakan pemberlakuan PT adalah terjadi pengurangan terhadap jumlah partai politik di parlemen. Pada pemilu 2009, hanya 9 partai politik yang akhirnya berhak untuk memperoleh kursi DPR dari 38 partai politik peserta pemilu. Secara prinsip MK memberikan dukungan positif kepada pembentuk undang-undang dalam mendesain kebijakan penyederhanaan partai politik di tengah situasi kerumitan sistem multi partai berhadap-hadapan dengan sistem presidensial. Apapun kebijakan pembentuk undang-undang, sepanjang tidak bertentangan dengan HAM maka kebijakan tersebut konstitusional:

Kebijakan seperti ini diperbolehkan oleh konstitusi sebagai politik penyederhanaan kepartaian karena pada hakikatnya adanya UndangUndang tentang Sistem Kepartaian atau Undang-Undang Politik yang terkait memang dimaksudkan untuk membuat pembatasan-pembatasan sebatas yang dibenarkan oleh konstitusi. Mengenai berapa besarnya angka ambang batas adalah menjadi kewenangan pembentuk Undang-Undang untuk menentukannya tanpa boleh dicampuri oleh Mahkamah selama tidak bertentangan dengan hak politik, kedaulatan rakyat, dan rasionalitas. ${ }^{22}$

MK tidak menafikan serangkaian upaya legislatif dalam rangka penyederhanaan partai politik sejak pemilu 1999.23 MK juga mengakui bahwa ET dan PT sama konstitusionalnya karena merupakan kebijakan pembentuk undang-undang yang sangat terbuka sesuai Pasal 22E ayat (6) UUD NRI 1945.24 Tetapi, jengah dengan kebijakan pembentuk undang-undang dalam rangka penyederhanaan partai politik yang berubah-ubah, MK kemudian mulai bersikap kritis. Adapun fokus dari kritik tersebut adalah desain kebijakan penyederhanaan partai politik ke dalam undang-undang yang sangat sarat dengan kepentingan politik. ${ }^{25}$

Putusan MK yang besar implikasinya bagi kegagalan upaya legislatif untuk penyederhanaan partai politik pada pemilu legislatif 2009 adalah Putusan No. 12/PUU-VI/2008 yang membatalkan keberlakuan Pasal 316 huruf 'd UU No. 10 Tahun 2008. Latar belakang munculnya Pasal 316 tidak terlepas dari Pasal 315 sebagai ketentuan peralihan dari pemberlakuan ET ke pemberlakuan PT ke dalam UU No. 10 Tahun 2008. Pasal

\footnotetext{
22 Putusan MK No. 3/PUU-VII/2009, Mahkamah Konstitusi, 13 Februari 2009, 130.

23 Ibid., 125-126.

24 Ibid., 126.

25 Ibid., 130-131.
} 
315 UU No. 10 Tahun 2008 menentukan:

Partai Politik Peserta Pemilu tahun 2004 yang memperoleh sekurangkurangnya $3 \%$ (tiga perseratus) jumlah kursi DPR atau memperoleh sekurang-kurangnya 4\% (empat perseratus) jumlah kursi DPRD provinsi yang tersebar sekurangkurangnya di $1 / 2$ (setengah) jumlah provinsi seluruh Indonesia, atau memperoleh sekurang-kurangnya 4\% (empat perseratus) jumlah kursi DPRD kabupaten/kota yang tersebar sekurang-kurangnya di $1 / 2$ (setengah) jumlah kabupaten/kota seluruh Indonesia, ditetapkan sebagai Partai Politik Peserta Pemilu setelah Pemilu tahun 2004.

Semangat dari Pasal 315 UU No. 10 Tahun 2008 adalah sebagai ET yang membatasi peserta pemilu 2009 berdasarkan perolehan suara pada pemilu 2004. Ketentuan ini sejatinya ditarik dari Pasal 9 UU No. 12 Tahun 2003. Sementara Pasal 316 UU No. 10 Tahun 2008 bersifat pengecualian terhadap Pasal 315, namun masih dengan semangat pembatasan:

Partai Politik Peserta Pemilu tahun 2004 yang tidak memenuhi ketentuan Pasal 315 dapat mengikuti Pemilu tahun 2009 dengan ketentuan:

a. bergabung dengan Partai Politik Peserta Pemilu yang memenuhi ketentuan sebagaimana dimaksud dalam Pasal 315; atau

b. bergabung dengan partai politik yang tidak memenuhi ketentuan sebagaimana dimaksud dalam Pasal 315 dan selanjutnya menggunakan nama dan tanda gambar salah satu partai politik yang bergabung sehingga memenuhi perolehan minimal jumlah kursi; atau

c. bergabung dengan partai politik yang tidak memenuhi ketentuan sebagaimana dimaksud dalam Pasal 315 dengan membentuk partai politik baru dengan nama dan tanda gambar baru sehingga memenuhi perolehan minimal jumlah kursi; atau

d. memiliki kursi di DPR RI hasil Pemilu 2004; atau

e. memenuhi persyaratan verifikasi oleh KPU untuk menjadi Partai Politik Peserta Pemilu sebagaimana ditentukan dalam Undang-Undang ini.

Pembatalan ketentuan Pasal 316 huruf ' $d$ tersebut dengan sendirinya menggugurkan seluruh klausul pembatasan kepesertaan partai politik dalam pemilu 2009 yang diatur dalam Pasal 315 dan 316 UU No. 10 Tahun 2008. Pasal 316 sendiri secara terbatas sebenarnya bersifat mengecualikan berlakunya Pasal 315 UU No. 10 Tahun 2008. Dengan demikian, implikasi dari Putusan No. 12/PUU-VI/2008, untuk kepesertaan partai politik dalam pemilu 2009 tidak memiliki pembatasan lagi. Satusatunya pembatasan yang masih berlaku adalah pembatasan yang sifatnya generalis, yaitu partai politik dapat menjadi peserta pemilu 2009 sepanjang telah memenuhi persyaratan verifikasi oleh KPU untuk menjadi Partai Politik Peserta Pemilu.

MK membatalkan Pasal 316 huruf

'd UU No. 10 Tahun 2008 dengan pertimbangan:

Bahwa Pasal 316 huruf d UU No. 10 tahun 2008 tidak jelas ratio legis dan konsistensinya sebagai pengaturan masa transisi dari prinsip electoral threshold ke prinsip parliamentary threshold yang ingin diwujudkan melalui Pasal 202 UU No. 10 tahun 2008;

Bahwa parpol-parpol Peserta Pemilu 2004, baik yang memenuhi ketentuan Pasal 316 huruf d UU No. 10 tahun 2008 maupun yang tidak 
memenuhi, sejatinya mempunyai kedudukan yang sama, yaitu sebagai Parpol Peserta Pemilu 2004 yang tidak memenuhi electoral threshold, sebagaimana dimaksud baik oleh Pasal 9 ayat (1) UU No. 12 tahun 2003 maupun oleh Pasal 315 UU No. 10 tahun 2008;

Bahwa Pasal 316 huruf d UU No. 10 tahun 2008 merupakan ketentuan yang memberikan perlakuan yang tidak sama dan menimbulkan ketidakpastian hukum (legal encertainty) dan ketidakadilan (injustice) terhadap sesama Parpol Peserta Pemilu 2004 yang tidak memenuhi ketentuan Pasal 315 UU No. 10 tahun 2008.26

Penulis berpendapat bahwa argumen MK tidak tepat. Pertama, ratio legis ketentuan tersebut sangat transparan sebagai bentuk pembatasan kepesertaan pemilu 2009. Kedua, ratio legis ketentuan tersebut menerapkan sistem "reward and punishment" terhadap semua partai politik peserta pemilu sebelumnya dikaitkan dengan hak untuk ikut serta dalam pemilu yang akan datang. Syarat dari Pasal 316 huruf 'd UU No. 10 Tahun 2008 ini telah diperlunak sedemikian rupa yaitu: "memiliki kursi di DPR RI dalam pemilu 2004"; hal ini berarti ET tidak diperhitungkan lagi. Konsekuensi dari ketentuan ini adalah partai politik yang tidak memiliki kursi di DPR RI hasil pemilu 2004 tidak dapat ikut serta dalam pemilu 2009. Ini adalah punishment kepada partai politik tersebut karena telah menyia-nyiakan kesempatan dalam pemilu 2004 dengan tidak memperoleh kursi DPR RI, di mana syarat tersebut berlaku sama kepada semua partai partai politik peserta pemilu 2004.

Menyongsong pelaksanaan pemilu legislatif 2014, pembentuk undang-undang telah merancang undang-undang sebagai dasar legalitas pemilu dengan UU No. 8 Tahun 2012 tentang Pemilihan Umum Anggota Dewan Perwakilan Rakyat, Dewan Perwakilan Daerah dan Dewan Perwakilan Rakyat Daerah- Pasal 208 UU No. 8 Tahun 2012 mengatur tentang mekanisme penentuan kursi DPR dan DPRD dengan ketentuan: "Partai Politik Peserta Pemilu harus memenuhi ambang batas perolehan suara sekurang-kurangnya 3,5\% (tiga koma lima persen) dari jumlah suara sah secara nasional untuk diikutkan dalam penentuan perolehan kursi anggota DPR, DPRD provinsi, dan DPRD kabupaten/kota." Pasal 208 UU No. 8 Tahun 2012 adalah penerapan kebijakan PT yang lebih berat dibandingkan dengan pengaturan serupa dalam Pasal 202 UU No. 10 Tahun 2008. Pasal 202 UU No. 10 Tahun 2008 hanya diberlakukan dalam penentuan kursi DPR sementara Pasal 208 UU No. 8 Tahun 2012 juga ditujukan untuk penentuan kursi DPRD provinsi dan kabupaten/kota. Pasal 208 UU No. 8 Tahun 2012 lebih mempersulit kehadiran partai politik di parlemen dengan menaikkan besaran PT (dari $2,5 \%$ menjadi $3,5 \%$ ) dan sekaligus diberlakukan untuk DPR maupun DPRD provinsi dan kabupaten/kota.

Kenaikan besaran PT ini diuji ke MK di mana MK masih kukuh pada pendiriannya bahwa besaran demikian tetap konstitusional sepanjang dalam penentuan perolehan kursi anggota DPR dengan menggunakan ratio decidendi seperti pada putusan No. 3/PUU-VII/2009, di mana penentuan besaran PT merupakan ranah kebijakan legislatif

26 Putusan MK No. 12/PUU-VI/2008, Mahkamah Konstitusi, 10 Juli 2008, 129. 
terbuka yang tidak akan di intervensi oleh MK manakala tidak bertentangan dengan hak politik, kedaulatan rakyat, dan rasionalitas. ${ }^{27}$ Sementara untuk penentuan perolehan kursi anggota DPRD provinsi dan DPRD kabupaten/kota, ketentuan ini dinyatakan inkonstitusional dengan ratio decidendi kekhawatiran akan hilangnya hak partai politik untuk mendudukkan wakil-wakilnya di DPRD provinsi dan di DPRD kabupaten/kota karena tidak mencapai PT 3,5\%.28

\section{Pemilu Legislatif dan Pemilu Presiden Serentak}

Pendapat yudisial MK paling kuat dalam mempertahankan sistem presidensial nampak dalam pengujian UU No. 42 Tahun 2008 tentang Pemilihan Umum Presiden dan Wakil Presiden. ${ }^{29}$ Isu utama dalam pengujian ini adalah periode penyelenggaraan pemilu presiden yang dilakukan setelah pemilu legislatif (Pasal 3 ayat [5] UU No. 42 Tahun 2008). Ide untuk melakukan permohonan pengujian adalah dengan mekanisme penyelenggaraan pemilu presiden yang demikian, dikaitkan dengan sistem multi partai, tidak akan mampu memperkuat sistem presidensial karena presiden terpilih cenderung sulit untuk memperoleh dukungan mayoritas parlemen.

Dengan penyelenggaraan pemilu legislatif dan pemilu presiden dilakukan serentak maka diharapkan akan terjadi efek penyederhanaan partai politik. Teori ini dinamakan coattail effect karena setelah memilih calon presiden, pemilih cenderung akan memilih partai politik atau koalisi partai politik yang mengusungnya. Teori ini berkembang berdasarkan pengalaman pelaksanaan pemilu legislatif dan pemilu presiden serentak di Brazil yang sistem politiknya multi partai sejak 1994. Dengan demikian, secara teoretis, semakin serentak pemilu legislatif dan pemilu presiden, semakin dapat dipetik manfaat konsolidasi baik untuk sistem kepartaian parlemen dan sistem kepartaian kepresidenan. 30 MK memberikan pendapat yudisial atas kasus ini sebagai berikut:

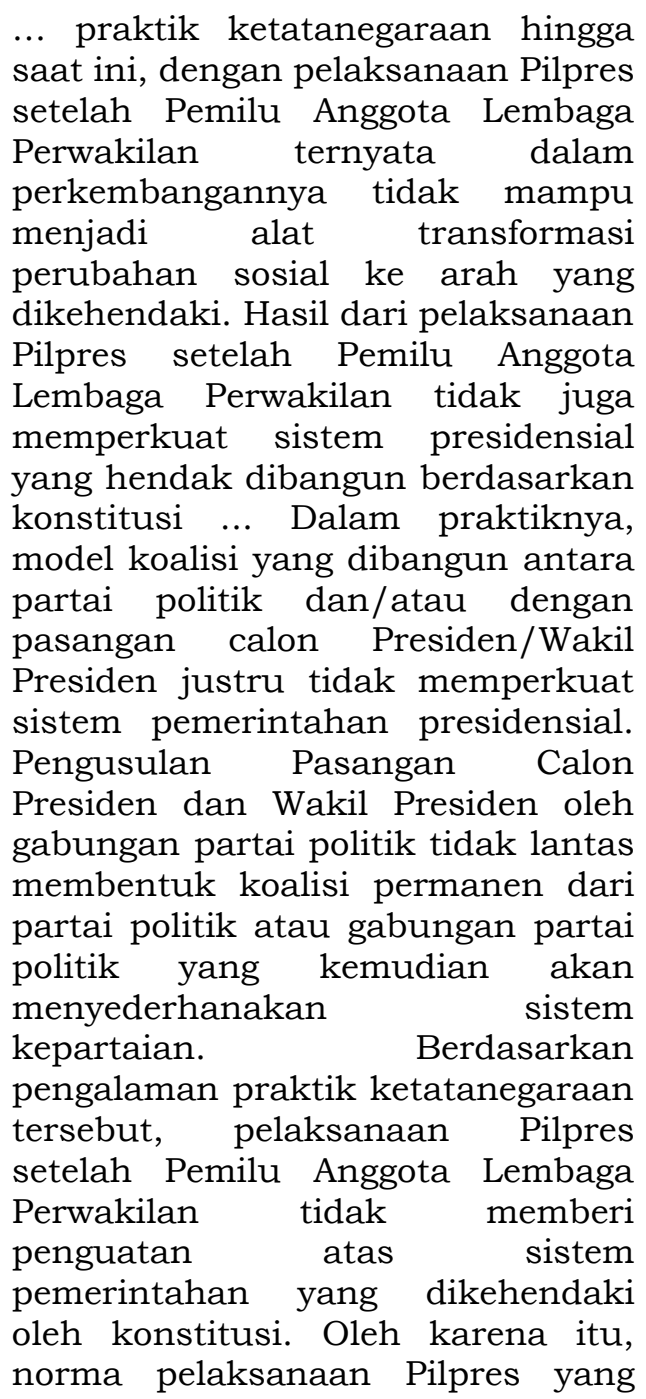

27 Putusan MK No. 52/PUU-X/2012, Mahkamah Konstitusi, 29 Agustus 2012, 95-98.

28 Ibid., 98-99.

29 Putusan MK No. 14/PUU-XI/2013, Mahkamah Konstitusi, 23 Januari 2014.

30 Ibid., 8-9. 
dilakukan setelah Pemilu Anggota Lembaga Perwakilan telah nyata tidak sesuai dengan semangat yang dikandung oleh UUD 1945. ${ }^{31}$

Seperti nampak dalam kutipan di atas, meskipun tidak secara eksplisit mendukung posisi teori coattail effect, MK bersikap kritis terhadap pengalaman dua kali pemilu legislatif dan pemilu presiden tidak serentak karena hasilnya tidak sejalan dengan semangat asas presidensialisme, dalam hal ini tidak kunjung efektifnya rekayasa sistem politik untuk penyederhanaan partai politik.

Oleh karena itu, a fortiori, hal ini dapat pula dimaknai secara tersirat bahwa ratio decidendi $\mathrm{MK}$ untuk sampai pada putusan bahwa pemilu legislatif dan pemilu presiden yang tidak serentak inkonstitusional adalah mendukung argumen pemohon bahwa salah satu alasan untuk pemilu legislatif dan pemilu presiden serentak adalah, salah satunya, teori coattail effect yang akan mampu secara efektif berdampak menyederhanakan sistem kepartaian kita. Akan tetapi, berdasarkan hasil pemilu 2019, terbukti bahwa fakta yang ada tidak sesuai dengan harapan MK yang membenarkan alasan pemohon.

\section{Presidential Threshold}

Isu yang bersifat implikatif dari penyelenggaraan pemilu legislatif dan pemilu presiden serentak adalah konstitusionalitas ketentuan Presidential Threshold (ambang batas pencalonan presiden) yang diberlakukan oleh Pasal 222 UU No. 7 Tahun 2017 tentang Pemilihan Umum (Pemilu). Ketentuan ini ditujukan bagi partai politik atau gabungan partai politik untuk dapat mengusung pasangan calon presiden/wakil presiden, yaitu: "memenuhi persyaratan perolehan kursi paling sedikit 20\% (dua puluh persen) dari jumlah kursi DPR atau memperoleh $25 \%$ (dua puluh lima persen) dari suara sah secara nasional pada Pemilu anggota DPR sebelumnya." Ketentuan ini dilakukan pengujian sebanyak dua kali ke MK, yaitu: Putusan No. 53/PUU-XV/2017 dan Putusan No. 49/PUU-XVI/2018. Poin penting dari pengujian ini adalah pendapat yudisial MK atas isu konstitusionalitas Pasal 222 UU Pemilu a quo. Poin penting dari isu konstitusionalitas Pasal 222 UU Pemilu dalam kaitan dengan asas presidensialisme adalah pendapat yudisial MK tentang relevansi keserentakan penyelenggaraan pemilu legislatif dan pemilu presiden yang didasari oleh pertimbangan presidensialisme. Itu artinya, konsistensi pendirian MK terkait dengan pendapat yudisialnya terdahulu menghadapi ujian di sini.

Jika, secara implisit, pemilu legislatif dan pemilu presiden serentak dimotivasi oleh penguatan asas presidensialisme supaya calon presiden/wakil presiden tidak tersandera oleh kepentingan politik partai politik, maka dalam pengujian ketentuan presidential threshold posisi MK justru bertolak belakang walaupun tetap mengklaim bahwa pendapat yudisialnya sudah sesuai dengan asas presidensialisme. Sikap ambigu MK nampak dalam pendapat yudisialnya sebagai berikut:

$\begin{array}{lr}\text { Argumentasi } & \text { teoretik } \\ \text { konstitusionalitas } & \text { persyaratan } \\ \text { mengenai ambang batas minimum } \\ \text { perolehan suara partai politik (atau } \\ \text { gabungan partai politik) untuk dapat } \\ \text { mengusulkan calon } & \text { Presiden dan } \\ \text { Wakil Presiden } & \text { bukanlah }\end{array}$


diturunkan dari logika disatukan atau dipisahkannya Pemilu untuk memilih Presiden/Wakil Presiden dengan pemilu untuk memilih anggota DPR, DPD, dan DPRD melainkan dari argumentasi teoretik untuk memperkuat sistem Presidensial dalam pengertian mewujudkan sistem dan praktik pemerintahan yang makin mendekati ciri/syarat ideal sistem pemerintahan Presidensial sehingga tercegahnya praktik yang justru menunjukkan ciri-ciri sistem Parlementer. ${ }^{32}$

Putusan ini tidak konsisten dengan pendirian MK dalam putusan yang pada akhirnya berimplikasi pada penyelenggaraan pemilu legislatif dan pemilu presiden serentak. Jika diikuti secara konsisten makna dari asas presidensialisme yaitu independensi eksekutif dari legislatif, maka presidential threshold seharusnya tidak relevan. Itu artinya, seharusnya, semua partai politik peserta pemilu legislatif berhak (sehingga bebas) untuk mengusung pasangan calon presiden/wakil presiden sendiri. Dengan pengertian lain, jika basisnya adalah presidensialisme, maka pengaturan tentang syarat pengusungan pasangan calon presiden/wakil presiden oleh partai politik adalah lebih memperhatikan figur atau sosok calon yang hendak diusung, bukan partai politik pengusungnya.33 Dissenting opinion Saldi Isra dan Suhartoyo justru lebih tepat dan konsisten dari perspektif asas presidensialisme, yaitu independensi eksekutif dari legislatif, ketika tidak setuju dengan keberlakuan presidential threshold:
Dalam sistem presidensial, melalui pemilu langsung, mandat rakyat diberikan secara terpisah masingmasing kepada pemegang kekuasaan legislatif dan kepada pemegang kekuasaan eksekutif (presiden). Karena sama-sama berasal dari pemilihan langsung, mandat yang diberikan kepada pemegang kekuasaan legislatif belum tentu sama, bahkan sejumlah fakta empirik membuktikan acapkali berbeda, dengan mandat yang diberikan kepada pemegang kekuasaan eksekutif. Menggunakan hasil pemilu legislatif guna mengisi posisi pemegang kekuasaan eksekutif merupakan logika dalam pengisian posisi pemegang kekuasaan eksekutif tertinggi dalam sistem parlementer. Artinya, dengan logika sistem pemerintahan, mempertahankan ambang batas (presidential threshold) dalam proses pengisian jabatan eksekutif tertinggi jelas memaksakan sebagian logika pengisian jabatan eksekutif dalam sistem parlementer ke dalam sistem presidensial. ${ }^{34}$

Dalam Putusan No. 49/PUUXVI/2018, sikap MK tetap tidak bergeming dalam menanggapi isu konstitusionalitas presidential threshold dengan menerapkan kembali ratio decidendi-nya dalam Putusan No. 53/PUU-XV/2017.35

\section{Kontribusi MK dalam Penegakan Asas Presidensialisme}

Pembahasan ini akan bersifat evaluatif, yang dalam hal ini mengevaluasi kontribusi MK dalam penegakan asas presidensialisme. Berdasarkan analisis deskriptif yang sudah dilakukan, kontribusi MK ada yang menunjukkan tren aktivisme mengarah pada praktik peranan

\footnotetext{
32 Putusan MK No. 53/PUU-XV/2017, Mahkamah Konstitusi 11 Januari 2018, 133.

33 Abdul Ghoffar, 'Problematika Presidential Threshold: Putusan Mahkamah Konstitusi dan Pengalaman di Negara Lain' (2018) 15 (3) Jurnal Konstitusi 480, 497.

$34 \quad$ Putusan MK (n 32) 141.

35 Putusan MK No. 49/PUU-XVI/2018, Mahkamah Konstitusi, 25 Oktober 2018, 44.
} 
sebagai policy-maker. Peranan ini, menurut Robert A. Dahl, dideskripsikan sebagai "arriving at decisions on controversial questions of national policy."36 Sementara, policymaking atau policy decision itu sendiri diberikan pengertian: "an effective choice among alternatives about which there is, at least initially, some uncertainty." 37 Oleh karena itu, policymaking secara normal sejatinya berada di ranah badan legislatif, dan ketika peran itu dilakukan badan yudisial maka tindakan tersebut dikualifikasikan politis. 38

Dalam kaitan dengan studi yudisial, aktivisme di sini mencerminkan adanya kecenderungan badan yudisial untuk menanggalkan "cultural norms of judicial role" tradisionalnya. 39 Konsepsi demikian mengandung makna peyoratif berupa kritik terhadap praktik yudisial dalam bentuk "the abuse of unsupervised power that is exercised outside the bounds of judicial role." 40 Atau dalam pengertian lebih spesifik lagi kecenderungan praktik yudisial yang "go beyond the Court's limitations and 'make' new law, rather than merely interpret it." 41
Pandangan positif atas praktik aktivisme yudisial diberikan oleh Aharon Barak yang menggunakan perspektif praktisi (hakim) dengan memberikan pemahaman bahwa praktik demikian dapat menjadi hal yang niscaya untuk ditempuh badan yudisial karena dia harus memenuhi harapan publik yang tinggi dalam demokrasi, sementara di sisi lain dia memiliki keterbatasan sarana dalam menjalankan fungsi yudisialnya itu. ${ }^{42}$ Oleh karenanya, dalam menilai apakah aktivisme yudisial itu praktik yang benar atau sebaliknya tentu pendekatan yang adil adalah pendekatan kasuistis berbasis hasil. Itu artinya, sisi positif atau negatif dari aktivisme yudisial bergantung pada kontribusinya apakah positif atau negatif. 43 Erwin Chemerinsky misalnya, menilai aktivisme yudisial the Rehnquist Court negatif karena tidak memiliki kepekaan terhadap isu hak-hak konstitusional. ${ }^{44}$ Sebaliknya, Archibald Cox menilai aktivisme yudisial the Warren Court positif dalam kaitan dengan pemajuan hak-hak konstitusional.45 Oleh karena itu Barak mengingatkan bahwa penilaian demikian haruslah: "a detailed examination of various aspects of the

\footnotetext{
36 Robert A. Dahl, 'Decision-Making in a Democracy: The Supreme Court as a National PolicyMaker' (1957) 6 (2) Journal of Public Law 279, 279.

Ibid.

38 Ibid. Bandingkan dengan Gerald N. Rosenberg, 'The Road Taken: Robert A. Dahl's Decision Making in a Democracy: The Supreme Court as a National Policy-Maker' (2001) 50 Emory Law Journal 613, 618-621. Craig Green, 'An Intellectual History of Judicial Activism' (2009) 58 (4) Emory Law Journal 1195, $1260-1261$. Ibid., 1222.

Richard L. Pacelle, Jr., The Role of the Supreme Court in American Politics: The Least Dangerous Branch (1st edn, Westview Press 2002) 11.

Aharon Barak, 'A Judge on Judging: The Role of a Supreme Court in a Democracy' (2002) 116 (1) Harvard Law Review 16, 126-127.

Titon Slamet Kurnia, Mahkamah Konstitusi Republik Indonesia: Sang Penjaga HAM (The Guardian of Human Rights) (1st edn, Penerbit PT. Alumni 2013) 144.

4 Erwin Chemerinsky, 'The Rhenquist Court and Justice: An Oxymoron?' (1999) 1 (1) Washington University Journal of Law and Policy 37, 44.

Archibald Cox, 'The Role of the Supreme Court: Judicial Activism or Self-Restraint?' (1987) 47 (1) Marryland Law Review 118, 129.
} 
judge or court and the overall results he or it produces." 46

Ada dua pendekatan yudisial yang digunakan MK dalam melakukan enforcement terhadap asas presidensialisme dalam pengujian undang-undang. Pertama, mendukung pembentuk undangundang dengan meng-endorse kebijakan legislatifnya dalam rangka penyederhanaan partai politik sepanjang masih cukup rasional. MK menggunakan standar yang disebut kebijakan legislatif terbuka untuk dasar konstitusionalitasnya. Hal ini terjadi baik dalam kasus electoral threshold, parliamentary threshold maupun presidential threshold. Pada kasus yang lain, MK tidak segan memberikan punishment yang keras, dengan mengambil peranan sebagai policy-maker, terhadap kebijakan legislatif yang dianggap tak kunjung efektif dalam mendesain penyederhanaan partai politik untuk memperkuat sistem presidensial. Untuk itu MK terlibat langsung dalam kebijakan positif untuk melakukan rekayasa sistem politik supaya kompatibel dengan tuntutan konstitusi, dalam hal ini asas presidensialisme, dengan mengkondisikan agar sistem politik (kepartaian) dapat berfungsi suportif terhadap sistem pemerintahan yang ditetapkan oleh konstitusi ketika menyatakan bahwa penyelenggaraan pemilu presiden setelah pemilu legislatif inkonstitusional. Dalam posisi demikian peranan MK dapat dikualifikasikan sangat aktif karena dalam kasus tersebut, pertentangan antara ketentuan undang-undang yang mengatur penyelenggaraan pemilu presiden dilakukan setelah pemilu legislatif dengan konstitusi tidak eksplisit. 47 Standar aktivisme yang digunakan di sini mengacu pada pendapat yang dikemukakan oleh James Bradley Thayer, yang merekomendasikan pendekatan selfrestraint kepada Mahkamah Agung Amerika Serikat ketika menguji konstitusionalitas undang-undang. ${ }^{48}$

Namun demikian, berdasarkan pembahasan di atas, pendapat yudisial MK dalam penegakan asas presidensialisme melalui pengujian undang-undang tidak selalu dilakukan secara konsisten, transparan dan tegas. Salah satu sisi positif dengan peranan MK dalam penegakan asas presidensialisme melalui pengujian undang-undang adalah membatasi pembentuk undang-undang supaya kebijakan legislatif dalam rangka penyederhanaan partai politik tidak sewenang-wenang dan melanggar HAM seperti pengalaman rezim Orde Baru yang melakukan penyederhanaan partai politik secara paksa justru untuk melemahkan peran parlemen dan partai politik sendiri. Dengan demikian penyalahgunaan dalam kekuasaan membentuk undang-undang dapat dihentikan meskipun putusanputusan MK tersebut tidak selalu tepat.

\footnotetext{
$46 \quad$ Barak, (n 42) 127.

47 Titon Slamet Kurnia, 'Prediktabilitas Ajudikasi Konstitusional: Mahkamah Konstitusi dan Pengujian Undang-Undang' (2016) 13 (2) Jurnal Konstitusi 259, 267-268; Titon Slamet Kurnia, 'Mahkamah Konstitusi sebagai Election Court: Refleksi Teoretis' (2018) 3 (1) Refleksi Hukum 33, 44-45.

48 James Bradley Thayer, 'The Origin and Scope of the American Doctrine of Constitutional Law' (1893) 7 (3) Harvard Law Review 129, 144.
} 
Pengertian tersirat dari peranan yang dijalankan oleh MK dalam rangka penguatan sistem presidensial di Indonesia adalah perlunya politik menyesuaikan diri dengan konstitusi, dalam hal ini asas presidensialisme. Presiden tidak boleh tersandera oleh kepentingan politik partai-partai politik. Kondisi tersebut bertolak belakang dengan marwah sistem presidensial yang mengharapkan karakter dari kekuasaan kepresidenan yang strong and energetic. Harapan tersebut jelas sangat sulit direalisasikan jika sistem politik di mana sistem presidensial beroperasi masih tetap sistem multi partai. Oleh karena itu, rekayasa sistem kepartaian melalui kebijakan legislatif dan putusan yudisial adalah keniscayaan dalam rangka penguatan sistem presidensial. Dengan hasil pemilu 2019 telah diketahui maka dapat diverifikasi bahwa eksperimen MK lewat Putusan No. 14/PUUXI/2013 untuk terjadinya penyederhanaan partai politik melalui penyelenggaraan pemilu legislatif dan pemilu presiden serentak ternyata tidak terjadi. Jika hasilnya positif maka peran MK dalam rangka memajukan kehidupan ketatanegaraan jelas tidak boleh disepelekan ketika turut terlibat aktif sebagai policy-maker. Tetapi sayang fakta berkata lain.

\section{PENUTUP}

Berdasarkan pembahasan di atas dapat disimpulkan bahwa MK memiliki kecenderungan kuat untuk mempertahankan asas presidensialisme dalam melakukan pengujian konstitusionalitas undangundang. Posisi MK tersebut mengandung aksentuasi supaya politik harus dilakukan sesuai konstitusi, dalam hal ini asas presidensialisme. Dalam menjalankan peranan tersebut adakalanya MK harus mempraktikkan aktivisme yudisial.

Meskipun persepsi MK dalam mempertahankan asas presidensialisme tersebut tidak selalu bersesuaian dengan kebijakan legislatif pembentuk undang-undang, namun MK tetap memberikan perhatian sangat serius pada isu penguatan sistem presidensial di Indonesia. Oleh karena itu, MK berani berspekulasi dalam melakukan pengujian atas konstitusionalitas penyelenggaraan pemilu presiden dalam UU No. 42 Tahun 2008 dengan hasil bahwa pemilu presiden yang diselenggarakan setelah pemilu legislatif inkonstitusional. Sebagai implikasinya, pemilu legislatif dan pemilu presiden pada tahun 2019 harus diselenggarakan serentak atau berbareng.

\section{DAFTAR BACAAN}

\section{Buku}

Bailey Jeremy D, Thomas Jefferson and Executive Power (1st edn, Cambridge University Press 2009).

Cheibub Jose A, Presidentialism, Parliamentarism and Democracy (1st edn, Cambridge University Press 2007).

Isra S, Pergeseran Fungsi Legislasi: Menguatnya Model Legislasi Parlementer dalam Sistem Presidensial Indonesia (1st edn, PT RajaGrafindo Persada 2010).

Kurnia Titon S, Mahkamah Konstitusi Republik Indonesia: Sang Penjaga HAM (The Guardian of Human 
Rights) (1st edn, Penerbit PT. Alumni 2013).

Kuswanto, Penyederhanaan Partai Politik: Penguatan Sistem Presidensial dalam Perspektif Pancasila dan Konstitusi (1st edn, Intelegensia Media 2016).

Mainwaring S, 'Presidentialism, Multipartism and Democracy: The Difficult Combination' dalam Robert A. Dahl, et.al., eds., The Democracy Sourcebook (1st edn, The MIT Press 2003).

Richard L. Pacelle Jr, The Role of the Supreme Court in American Politics: The Least Dangerous Branch (1st edn, Westview Press 2002).

Strong C F, Modern Political Constitution (5th edn, Sidwick dan Jackson Ltd. 1975).

\section{Artikel Jurnal}

Ackerman B, The New Separation of Powers' (2000) 113 (3) Harvard Law Review.

Barak A, 'A Judge on Judging: The Role of a supreme Court in a Democracy' (2002) 116 Harvard Law Review.

Calabresi Steven G, The Virtues of Presidential Government: Why Professor Ackerman is Wrong to Prefer the German to the U.S. Constitution' (2001) 18

Constitutional Commentary.

Chemerinsky E, 'The Rhenquist Court and Justice: An Oxymoron?' $\begin{array}{lll}\text { (1999) } 1 & \text { (1) Washington }\end{array}$ University Journal of Law and Policy.

Cox A, The Role of the Supreme Court: Judicial Activism or SelfRestraint?’ (1987) $47 \quad$ (1) Marryland Law Review.

Dahl Robert A, 'Decision-Making in a Democracy: The Supreme Court as a National Policy-Maker' (1957) 6 (2) Journal of Public Law.
Ghoffar A, 'Problematika Presidential Threshold: Putusan Mahkamah Konstitusi dan Pengalaman di Negara Lain' (2018) 15 (3) Jurnal Konstitusi.

Green C, 'An Intellectual History of Judicial Activism' (2009) 58 (4) Emory Law Journal.

Kurnia Titon S, 'Prediktabilitas Ajudikasi Konstitusional: Mahkamah Konstitusi dan Pengujian Undang-Undang' (2016) 13 (2) Jurnal Konstitusi.

Kurnia Titon S, 'Mahkamah Konstitusi sebagai Election Court: Refleksi Teoretis' (2018) 3 (1) Refleksi Hukum.

Linz Juan J, 'The Perils of Presidentialism' (1990) 1 (1) Journal of Democracy.

Mainwaring S, dan Matthew S, 'Juan Linz, Presidentialism and Democracy: A Critical Appraisal' (1993) Kellog Institute for International Studies, Working Paper No. 200.

Mainwaring S, dan Matthew S. S, 'Juan Linz, Presidentialism and Democracy’ (1997) $29 \quad$ (4) Comparative Politics.

Rose-Ackerman S, Desierto Diane A, dan Volosin N, 'HyperPresidentialism: Separation of Powers without Checks and Balances in Argentina and the Philippines' (2011) 29 (1) Berkeley Journal of International Law.

Rosenberg Gerald N, The Road Taken: Robert A. Dahl's Decision Making in a Democracy: The Supreme Court as a National Policy-Maker' (2001) 50 Emory Law Journal.

Skach C, 'The 'Newest' of Separation of Powers: Semipresidentialism' (2007) 5 (1) International Journal of Constitutional Law.

Thayer James B, The Origin and Scope of the American Doctrine of Constitutional Law' (1893) 7 (3) Harvard Law Review. 


\section{Tesis/Disertasi}

Safa'at Muchammad A, Pembubaran Partai Politik di Indonesia: Analisis Pengaturan Hukum dan Praktik Pembubaran Partai Politik 1959-2004 (Disertasi, Universitas Indonesia 2009).

\section{Putusan Pengadilan}

Putusan Mahkamah Konstitusi Nomor 002/PUU-II/2004, Mahkamah Konstitusi, 22 April 2004.

Putusan Mahkamah Konstitusi Nomor 16/PUU-V/2007, Mahkamah Konstitusi, 23 Oktobern 2007.

Putusan Mahkamah Konstitusi Nomor 3/PUU-VII/2009, Mahkamah Konstitusi, 13 Februari 2009.

Putusan Mahkamah Konstitusi Nomor 002/PUU-II/2004, Mahkamah Konstitusi, 22 April 2004.

Putusan Mahkamah Konstitusi Nomor 12/PUU-VI/2008, Mahkamah Konstitusi, 10 Juli 2008.

Putusan Mahkamah Konstitusi Nomor 52/PUU-X/2012, Mahkamah Konstitusi, 29 Agustus 2012.

Putusan Mahkamah Konstitusi Nomor 14/PUU-XI/2013, Mahkamah Konstitusi, 23 Januari 2014.

Putusan Mahkamah Konstitusi Nomor 53/PUU-XV/2017, Mahkamah Konstitusi, 11 Januari 2018.

Putusan Mahkamah Konstitusi Nomor 49/PUU-XVI/2018, Mahkamah Konstitusi, 25 Oktober 2018. 
